\title{
RESEÑAS
}

Alberto Zum Felde, Indice critico de la literatura bispanoamericana. La narrativa, Editorial Guarania, México, 1959.

Este segundo volumen de la gigantesca obra emprendida por el crítico uruguayo Alberto Zum Felde es tan enjundioso como el primero - sobre el ensayo-, aunque no tan nitidamente estructurado. En quinientas y tantas páginas de apretada tipografía el autor pasa revista a diversas formas de literatura narrativa hispanoamericana, plantea doctrinas sociales, económicas, filosóficas, estéticas, enjuicia aspectos importantes de la cultura europea y no desdeña el arte del vati. cinio, el trance místico y la caprichosa divagación poética.

El libro de Zum Felde no es una historia del género narrativo en Hispanoamérica. Se trata, más bien, de una extensa y profunda especulación sobre los rumbos que han asumido nuestra novela y cuento a través del siglo XIX y lo que va del xx, y acerca del impulso que a esos rumbos le han dado algunos autores de prestigio. En su teorización el autor parte de una premisa fundamental:

"La aarrativa hispanoamericana-dice- en general entraña el esfuerzo y proceso de adaptación del hombre (del universal) a las condiciones de una doble realidad, telúrica e históricamente dada, propia del Continente, con sus variantes regionales; en lo geográfico, conflicto y adaptación del hombre con respecto a la naturaleza, cuyas poderosas fuerzas territoriales (pampas, selvas, y montañas) van modelando en gran parte sus caracteres y sus hábitos; en lo histórico, conflicto y adaptación de la cultura occidental moderna a las viejas estructuras psíquicas y sociales de la tradición colonial, la que, a su vez, y en relación con los factores territoriales, han moldeado hereditariamente, en parte, costumbres y caracteres." (p. 11)

De estas dos realidades a que alude el autor, la primera es, sin duda, la que más le fascina. A ella le confiere una significación predominante en la evolución de la narrativa hispanoamericana. Lo afirma sin ambages:

"Anótese que las mayores novelas americanas, así del xIx como del $\mathrm{xx}$, son novelas del campo; lo territorial absorbe lo urbano. Es que allí, en el campo, se plantea lo más arduo y dramático de esa lucha geo-humana; y allí también, por ende, se da lo más original y fuertemente característico del Continente." (p. 12) 
La novela hispanoamericana, según Zum Felde, crece en torno a los conflictos de un hombre regional, a diferencia de la europea que se preocupa de un hombre universal. Tesis es ésta que ha sido ya expresada muchas veces aunque, tal vez, no con el vigor y la hondura del crítico uruguayo; hoy, ella es insostenible y parecerá sacrílega a quien haya seguido la producción de los novelistas de las tres últimas generaciones. México, Chile, la Argentina, el Ecuador, Cuba y Guatemala - para no nombrar sino aquellos países de más intensa creación no. rclística en estos momentos- han superado definitivamente el regionalismo a que alude Zum Felde. Quien desea aquilatar el peso y la trascendencia estética de la novela hispanoamericana no lee ya a los cronistas de la revolución mexicana sino a Agustín Yáñez, ni a los criollistas que glorificaron las faenas del gaucho sino a Eduardo Mallea o a Jorge Luis Borges o a Ernesto Sábato o Juan Carlos Onetti, ni a los costumbristas hispano-tropicales sino a Asturias, Carpentier o Monteforte Toledo. Unos y otros han cumplido una función de relieve en el desarrollo de la novela hispanoamericana, pero aquéllos-los criollistas- la cumplieron dentro de una órbita local, mientras que éstos la cumplen en un plano de valores universales. Zum Felde busca una tónica y la busca a través de siglo y medio de producción literaria, no sólo en la época contemporánea. Aceptado. Lo que discuto es su perspectiva; es decir, creer que el regionalismo del pasado por inamovible deba considerarse clásico y por clásico característico de una literatura. No niego la comodidad de aceptar el pensamiento estético de una época, que ya dio sus obras maestras, como representativo de otra época de transición. Es la comodidad de todas las ilusiones ópticas. Se nos conoce por el impresionismo dramático y desorbitado de una literatura narrativa que, remedando ciertos estilos europeos de novelar, se preocupó de reproducir el impacto de la naturaleza salvaje sobre el hombre moderno; se nos dio fama de pintorescos, de feístas y predicadores. Zum Felde cree necesario estructurar la compleja red de conceptos que dará méritos teóricos a esa fama. En el proceso despliega sólida argumentación y amplia sabiduría. Convencerá a quienes estén de acuerdo con él de antemano, fortaleciéndoles en su posición y enriqucciéndoles con nuevos elementos de juicio.

Aceptemos su predicado básico y, siguiéndole sin contradicciones a través de sus extensas elucubraciones, llegaremos al final de la obra con la certeza de haber descubierto nuevos fondos en un panorama que, por lo general, se nos ofrece únicamente desde ángulos superficiales. Los seis capítulos en que se divide el libro de Zum Felde, y los densos esquemas que les preceden, son como mares gruesas que en cada montaña de agua acumulan mucha materia heterogénea y ba rren otro tanto al retirarse. La materia que exponen viene acondicionada por el credo estético del autor. La Introducción General, por ejemplo, define ese credo y ordena un número de novelas ilustrativas dentro de cuatro categorías: indianistas, proletarias, revolucionarias (dentro de la Revolución Mexicana) y costumbristas o pictóricas. No todas las novelas mencionadas por el autor (pp. 48-50) se ajustan a la categoría que él les asigna. Porque ¿puede afirmarse que Don Goyo y Los Sangurimas son novelas indianistas?, y ¿puede decirse que $L a$ fábrica de Sepúlveda Leyton es novela proletaria? Como se sabe, la "fábrica" de que habla el novelista chileno es la Escuela Normal de Preceptores de Santiago. El título engaña. Pero, Zum Felde mismo declara que cita "muy sucintamente" y un poco al 
azar". . El segundo capítulo, asimismo, es una apretada y exacta apreciación de la novela romántica hispanoamericana sobre la base de un criterio fijado a priori.

"De entre el conjunto de la narrativa de tema histórico que se escribe en el largo período romántico-su tema-durante casi medio siglo, mediocre en lo más, es claro, aunque en algunas obras excelente, podrían asumir la máxima representación del género, en sus cuatro motivaciones principales, y en su orden -a saber: la Indígena, el Coloniaje, la Emancipación, la República-, éstas que citaremos, por ejemplo: Cumandá de Juan León Mera; Tradiciones peruanas de Ricardo Palma; Ismael de Acevedo Díaz; Amalia de José Mármol." (p. 90)

En este caso, las cuatro obras mencionadas le sirven al autor para destacar los elementos característicos de la novela romántica hispanoamericana sin necesidad de atiborrar al lector con referencias a obras de dudosa importancia.

Los capítulos tercero y cuarto - "La narrativa realista" y "La novela realista intrahistórica de América"- encierran la médula del pensamiento de Zum Felde; en ellos ausculta el fondo regionalista de la novela hispanoamericana a través de los últimos años del siglo xIX y la primera mitad del xx, discute la dualidad modernista-realista de los años del veinte al treinta y estudie minuciosamente las relaciones entre lo social y lo estético en la obra de algunos autores que le atraen particularmente. El realismo de nuestros escritores, según Zum Felde, ha sido siempre moralizador y reformista; de ahi que las grandes causas sociales que han movilizado a los pueblos hispanoamericanos encuentren eco tan amplio y entusiasta en la novela y en el cuento. La emancipación del indio, la revolución agraria y anti-imperialista de México, las crisis políticas de Venezuela y Cuba, los conflictos políticos de la región del Plata, las guerras civiles centroamericanas, son aspectos históricos que constituyen temas fundamentales de nuestra literatura narrativa. Tanto énfasis pone Zum Felde en destacar la significación de esa novelística realista que, por contraste, la novela de tendencia estética aparece desleída e intrascendente.

"Las desviaciones de esta ruta (la realista) -afirma- en aventuras de índole esteticista o psicologista, al margen de sus direcciones generales, en parte semifrustradas, en razón de su artificiosidad y su exotismo con respecto al medio social americano - aun al de las ciudades-, como faltas de ambiente para respirar, se asfixian, pasan al museo literario como raras muestras de tipos de inadaptación." (p. 151)

Como ejemplos cita obras de Reyles, Dominici, Clemente Palma, Augusto Aguirre Morales y otros. ¿Y Alsino? ¿Y La sombra del bumo en el espejo? ¿Y los cuentos de Arévalo Martínez? ¿Pueden descartarse estas obras como simples despliegues de exotismo artificioso? El fondo regional de Alsino-la raíz te. lúrica del mito-es precisamente uno de los. milagros del arte modernista his. 'panoamericano. Zum. Felde no desdeña la novela artística que se forjó en la tradición dariana. Le dedica un capitulo, el quinto; tampoco pasa por alto las creaciones del trascendentalismo de medio siglo: las estudia en el último capítulo como "modalidades suprarrealistas"; pero, al ocuparse de estas tendencias el vigor de su especulación decae; parece observarlas en un continuo paréntesis, ansioso de cerrarlo y volver al tema social que le fascina. Aún asi, deja páginas magnificas sobre autores como el argentino Roberto Arlt, hasta hoy figura de élite, sobre Mallea, Sábato, Borges y otros novelistas y cuentistas de la Argentina y 
del Uruguay, cuya obra literaria se relaciona más con la psicología y la filosofía que con los problemas económicos y sociales de Amética.

¿A quién debe recomendarse el libro de Zum Felde? ¿Al estudiante de literatura hispanoamericana? Creo que no; a menos que el estudiante se haga guiar por un experto que corrija los numerosos gazapos, complete la nómina de novelistas (aunque parezca increible, entre los autores chilenos que Zum Felde no menciona está Manuel Rojas...) y exponga aquellas doctrinas que, aunque opuestas al pensamiento del autor, son indispensables para comprender debidamente la evolución en conjunto del género narrativo en Hispanoamérica. Más bien, es obra ésta para el especialista, a quien los errores de detalle no molestan y quien, en cambio, gozará con la divagación de alto vuelo y la energía y densidad intelectual que son características del ensayista uruguayo.

Universidad de California,

Fernando Alegría

Berkeley, California.

Arturo Torres-Rroseco, Madurez de la muerte, Valencia. Editorial Castalia. 1959.

Esta obra del profesor Torres-Rioseco contiene un conjunto de poemas en verso cuya temática común queda sintetizada en el título. La homogeneidad de contenido apenas le permite al autor apartarse de los recuerdos de un medio distante en el tiempo y en el espacio, pero vivo en la sensibilidad del poeta, para darse a la evocación de figuras humanas ya idas del mundo circundante, pero presentes en el legado espiritual que nos dejaron por una eternidad: Gabriela Mistral, Jorge González Bastías y Amado Alonso. La vitalidad poética del autor, lejos de agonizar, se proyecta ágil e impresionable en la fisonomía de la ciudad desierta, en el vuelo estelar de la gaviota y en la ausencia de la luna con todo su cortejo de muerte de juncos y una razón de amor. Con igual flexibilidad, el poeta exterioriza el contenido íntimo de su fina emotividad al verterse en un pregón por dentro, bien estatuido en la integridad de los repetidos versos, "me estoy poniendo viejo". Vale esta revisión de materias, si en algo hace justicia al autor, por un sumario de los contenidos esencialmente líricos que se nos proporcionan y que procuramos subrayar.

Al dinamismo interno de la temática y los contenidos, agreguemos unas cuantas observaciones referentes a la forma para acaso llegar a una justa aproximación de los méritos fronterizos de la creación. No se trata de un poeta joven y sin la experiencia de las nuevas generaciones en el manejo de los moldes poéticos. Torres-Rioseco une a su acabado conocimiento de la métrica, por algo es catedrático, la ecuanimidad creadora que pone en jaque todo exceso renovador. De ahí que corran a la par el residuo tradicional establecido y la comunicación entre artista y lector con el estímulo tonificante del vanguardista que nos avanza sin ocultismos ni jeroglíficos. 
La variación tonal de elevados y puros matices no excluye la inmediata incorporación de los motivos cercanos observados, "mis zapatos gastados / dientes de tedio en las mañanas... / mi camisa bosteza", lo cual en nada desdice ni disuena con el canto de la gaviota o el vuelo inspirador de ésta, "y se eleva en el aire de repente, / nieve de pluma contra sol de oriente/ en la marea verde de los pinos". La receptividad del poeta se mantiene blanda y fértil sin que deje en desmedro o a la zaga la riqueza expresiva del modelador literario. A la multitud de imágenes internas, vatiadas en estampa, tono y matiz, corresponde igual variedad de realizaciones verbales. Abundan, pues, por doquier los motivos y fuentes de concepciones que parecen enriquecer la vitalidad espiritual de Torres... y con el correr de los años, aunque él parezca temerlo, sus versos lejos de añejarse o de agonizar, se nos convierten en bálsamo de estimulante frescor.

No es que el poeta ignore su sino, pues a menudo retorna en una forma $\mathfrak{u}$ otra a aquello de "mi cuerpo carnal, / triste ser perecedero / que quiere ser verdadero / siendo imagen terrenal/" etc., pero tampoco suspira, ni renuncia, ni desespera con disfraces, pues a la muerte en vida e inevitable con la prespectiva de un más allá, le dice con calma desafiante, "ya no temo tu venida, / antes ya temo perderte, / y quedarme con la vida / desamparado e inerte /." No falta el consuelo que parece vislumbrarse con optimismo en los versos dedicados a la Mistral, a Alonso y, sobre todo, a González Bastías, "atrás quedó su sombra, / su voz cantante, / voz de hoja en la noche.../ se fue solo, con versos/que salían como agua / de sus labios / hacia la mar cercana".

Nuestra inpresión crítica no es fija ni normativa porque los versos de TorresRioseco no son para delirar ni enloquecer, pero tampoco desconciertan o precipitan al vacio sumiéndonos en el ámbito de lo críptico. Admiramos, y con sinceridad, su permanencia temática, su firme y constante renovación expresiva, la fecunda sensibilidad de su ser poético y la fácil comunicación que, como autor, logra establecer con quien desee saborear los frutos de sus personales experiencias y la espontánea delicadeza de su bien llevada creación.

Universidad de Nortbwestern

Homero Castillo

Evanston, Illinois.

Víctor M. Valenzuela, Hombres y temas de Iberocmérica, New York, Las Américas Publishing Company, 1959.

Muy plausible es la iniciativa que han tenido algunos profesores universitarios de los Estados Unidos al tecopilar los ensayos por ellos escritos para diversas revistas y hacerlos publicar en forma de libros. Junto con facilitar la tarea de ubicar rápidamente los estudios, estos tomos permiten apreciar la orientación crítica que los autores han impreso a su obra, familiarizándose con el conjunto de temas que a ellos les han interesado $y$, en general, tener una idea aproximada de la calidad y el volumen que ha logrado alcanzar la labor nada despreciable realizada por 
el magisterio universitario norteamericano en el campo de la crítica y la investigación literaria.

La obra que reseñamos a continuación cae dentro del esquema descriptivo que acabamos de bosquejar. Comprende diez artículos de Víctor M. Valenzuela, profesor de la Universidad de Lehigh que ha escogido los temas más representativos de su repertorio crítico para con ellos formar un tomito que revela lo distintivo de su labor y el método empleado para atacar los tópicos que se ha propuesto brindar al público lector.

Cronológicamente el temario de este libro abarca un período bastante extenso pues comprende ensayos sobre autores contemporáneos, que son los más, tales como Alfonso Reyes, Marta Brunet y Gabriela Mistral, y también otros de comienzos de siglo, Baldomero Lillo, por ejemplo, o autores de ya lejanos pasados, como Pedto de Valdivia.

El panorama temático revela también un vasto campo que va desde la literatura a la filosofía y del estudio de un autor o de un aspecto de su producción a movimientos de carácter amplio y general. No se circunscribe el profesor Valenzuela a estudiar el fatalismo en la obra de Marta Brunet, el modernismo de Baldomero Lillo u otros tópicos especiales, sino que enfoca la totalidad de la producción de autores como la Mistral o Alfonso Reyes para así dar relieve al conjunto o a algunos rasgos sobresalientes que han captado la atención y el interés del crítico.

A veces el autor penetra en el campo filosófico y realza algunas facetas del pensamiento de ciertos ideólogos, como Jorge Millas y Waldo Ross, o se embarca en temas generales de gran amplitud. Entre éstos se encuentran el de la originalidad en la filosofía del Brasil, el concepto de logosofía en la obra de Carlos Bernardo González Pecotche, las consideraciones personales que hace el mismo Valenzuela sobre la soledad y los juicios que a él le merece la eterna pero desatinada política de prohibir libros para así acallar las manifestaciones del espíritu y coartar su posible y perniciosa influencia.

El procedimiento que sigue el autor para abordar la materia de sus ensayos, desarrollar los problemas que plantea y ofrecer aiguna conclusión, en general consiste en estatuir los conceptos básicos que él desea adelantar y luego probarlos con datos informativos ya bien establecidos o con citas ilustrativas y directas de los textos. En ambos casos la corroboración es de tipo enumerativo y amplio, puesto que se basa en una copiosa diversidad de obras, o trae a colación un abundante número de hechos ya bien conocidos e indiscutibles. En algunas ocasiones la índole misma de la materia obliga a estrechar el marco de las pruebas, como ocurre al analizar las pocas cartas legadas por Pedro de Valdivia o la escasa obra publicada por Millas o por Ross. Sin embargo, y si las circunstancias se lo permiten, Valenzuela recurre con rapidez a la producción casi completa de autores como Reyes, la Mistral o Marta Brunet, o nos pasea por un dilatado espacio de tiempo para extractar los datos que busca afanosamente. Esto último ocurre, por lo común, al ofrecer tópicos de carácter general, como la visión panorámica que se propone darnos de la filosofía en Brasil y Portugal desde el siglo xvi hasta el xx o al inventariar los libros prohibidos partiendo de la tercera, centuria antes de Cristo y rematando en los tiempos actuales.

Al bosquejar el contenido y la metodología de este libro, hemos procurado poner de relieve la variada cantidad de temas que trata el autor, así como la técnica 
elaborativa que ha utilizado. Indirectamente hemos dejado de manifiesto el acopio de lecturas que ha llevado al crítico a interesarse en tantos campos del saber. Notamos, asimismo, las muchas inquietudes que en él han despertado ciertos temas y percibimos la intención que le ha guiado de compartir con los lectores las reflexiones e impresiones que le han suscitado las obras con que ha estado en contacto durante algunos años de su vida.

Bien ha hecho el profesor Valenzuela en divulgar los conocimientos que ha adquirido merced a la dedicación al estudio que demuestra. De idéntico interés son las impresiones que le han dejado las lecturas y las sugerencias que éstas han hecho surgir en su espiritu.

Universidad de Northwestern

Homero Castillo

Evanston, Illinois.

José Agustín Balseiro, Visperas de sombra y otros poemas. México. Ediciones de Andrea [Los Presentes, 75], 1959.

El crítico y poèta puertorriqueño que presidió el VIIL Congreso del Instituto Internacional de Literatura Iberoamericana, en 1957, ha publicado un nuevo libro que encierra la última cosecha de su percepción artística: "Vísperas de Sombra y otros poemas". La obra con tan sugestivo nombre se divide en tres partes: I. "Vísperas de Sombra" (págs. 9-33); II. "Intermezzo: Canciones de niñez y adolescencia" (págs. 35-51); y Ill. "Este tiempo nuestro" (págs. 53-78. Balseiro sigue en su fórmula estética un itinerario consciente y temporal que le da coherencia a la obra. La primera parte se desarrolla en la oscuridad, que es el principio estético de la creación, donde predomina la duda. La segunda, revela optimismo; el optimismo del poeta que sirve de puente hacia la redención del hombre, aquí nos conduce al último trecho de su camino interior, en el cual se impone la angustia.

Los mismos títulos "Vísperas de Sombra", "Vigía de Crespones", "Paraíso en tinieblas", "E1 silencio irrevocable", "Rosa de paz", "Interrogaciones", "¿Cuál la hora?", "La travesía ciega", "¿Cómo será el partir?", "Más allá de la sombra" revelan el tono de la primera división. En ella se interpreta la tragedia del hombre que presiente el término del ciclo vital. El poema que le da nombre al libro descubre el estado de ánimo del autor. Con los "párpados cansados" y el "barro adolorido" de su cuerpo que le pesa como plomo siente venir a la muerte y, duda porque ignora la composición metafísica de la muerte, si es puente que nos une al reino de la sombra ("si puente abierto al horizonte oscuro"), o si es un micro-desmayo que nos conduce a otra vida luminosa ("ala de niebla que a la luz renace"). La igno. rancia es tanto acerca de la muerte como del arcano más allá. Pero no importan las respuestas; cualesquiera que sean, la disposición del poeta es la misma. Está preparado a recibir a la "mensajera homicida de la Nada", al "heraldo inevitable de la Sombra", porque está cansado de recibir los martillazos que nos da la vida en este valle de penurias. La actitud pasiva del poeta es lo más subjetivo de su 
mensaje; se resigna a ver al mensajero huesudo de la capa negra que empuña la guadaña, y se resiste a escapar porque no espera más de la vida: "No bogaré la barca de Caronte / por mares que me asombren con sus signos: / que corazón donde cayó la noche / no quiere auroras, sólo tıene olvidos". Esta mansedumbre es la del hombre agobiado por el llanto de ayer, el hombre terminado. Cuando llegue el mensajero, nuestro autor se encontrará prevenido y listo a emprender el viaje sin retorno, a comenzar la eterna ausencia. Del último verso citado se colige que su actitud se parece a la de las ánimas griegas que viajan en la barca de Carón, ansiosas de beber el agua que les hará olvidar la vida terrenal. Aquí la concepción de Balseiro difiere de la de Dante, y por esta razón habrá que recor. darle que aquel viaje no debe hacerse sin el óbolo para el anciano barquero avaro de la laguna Estigia.

Como se ve, o mejor, como se siente, las pinceladas del poema son oscuras; las ideas abstractas están impregnadas del tinte negro que expresan las palabras: sombra, horizonte oscuro, ala de niebla, nocbe, y la suma de adjetivos y sustanti vos negativos: fatigados, trance, fuga, adolorido, pena, angustiado, queja, invisible, misteriosa, secreta, llanto, olvidos, ausencia. $\mathrm{Y}$ aunque no necesitamos compartir el pesimismo de esta etapa, sí podemos ver que estas palabras sirven de cimiento en la arquitectura poética del autor. La composición es sencilla. Tiene ocho estrofas de versos asonantados. La primera es la única que tiene cinco versos, de los cuales sólo el segundo es heptasílabo, los demás endecasílabos. Las estrofas restantes están compuesta de cuatro versos endecasílabos, con excepción de la quinta estrofa, cuyo segundo verso es heptasílabo también mientras que los otros tres son endecasilabos.

En el segundo poema, "Vigía de Crespones", el verso libre ofrece más ritmo interior y predominio de imptesiones sensoriales:

El Angel de la Luz plegó sus alas

en el hondón del alma.

El Angel de la Sombra se presenta

a pisar con su pie mi noche en vela.

Doble par de versos rematados con una exclamación: "¿Qué largas mis horas, qué largas!" En seguida irrumpe la duda en versos interrogativos:

(¿Mías, o del Destino?

¿Mías, o de la Nada?

Sobre las hojas del cristal del río

¿quién leerá los signos cuando pasan?)

¿Dónde el tiempo o el fin, dónde la meta

que cierra la jornada?

Las preguntas le arrancan la misma exclamación sobre la larga duración del tiempo. En una estrofa Balsciro nos dice con angustia vallejeana que el mundo, des- 
habitado como un túnel "se vacía en su abismo como saco / roto de huesos y de penas". Los ojos interiores no pueden ver los imposibles mañanas y siente en las sienes los punzones de la angustia. Si en esta esttofa sentimos los gritos del Vallejo de Trilce, en la siguiente la carga afectiva que emana de ella se asemeja a la que nos comunica Lorca al ver a la guardia civil acercarse ominosamente:

Bajo el grito de soles de tortura, bajo el luto de nubes que no llegan

a ser lluvia,

la carne que fue ayer pasión frenética retuércese de angustia.

Las pupilas se ciegan entre los helados cristales sin reflejo, y las navajas de la luna prueban

su filo en las espigas de mis nervios.

Después de distinguir al vigía de crespones negros que hace guardia entre el misterioso horizonte nublado, el poeta lanza su grito postrero: "iQué largas mis horas, qué largas!".

En chino, la idea árbol se representa con el ideograma de un árbol estilizado; la idea bosque, con dos de estos ideogramas que forman un solo carácter. Balseiro hace lo mismo en "La travesía ciega". Del verso "Un árbol y otro arbol y otro árbol..." crea "El bosque más áspero a cada paso". Frente a esta transformación cuantitativa del árbol convertido en bosque, el poeta se convierte en ángel: "Y yo, más que en mis pies, sobre la tierra / flotando y flontando, y flotando". Pero este poeta-ángel no puede ver la meta porque se encuentra "en prisión sin indultos y sin plazos" formada por los troncos de los árboles. Esos troncos que le impiden la visión y la libertad son las barras de su cárcel. Aunque se estrella contra las cortezas que le rompen la carne, y contra las ramas, que se hunden en sus venas, el escritor puertorriqueño no siente; su sangre ya no circula, se ha coagulado: "La sangre no circula, toda quieta/y hecha rosas moradas en mis flancos". Del plano de la vida ha pásado al de la muerte. El follaje oscurece el panorama sin darle la esperanza de una nueva aurora: "El follaje es de noche y ha cerrado/la luz sin la promesa / de amanecer". De pronto un relámpago ilumina la visión pesimista del poeta y le hace ver la prisión perpetua en el ataúd: "y me veo por siempre aprisionado / en cuatro tablas que no tienen puerta..." Y así termina el poema, mostrándonos con transformaciones cuantitativas y cualitativas la travesía de la vida a la muerte, la que nosotros para simplificar reduciremos a dos hileras de palabras:

átbol, bosque, tronco, tabla, ataúd oscuro

hombre, poeta, ángel, cadáver desesperanzado.

Se dirá que en la primera parte hay indecisión porque nuestro autor pasa de la rima asonantada al verso libre. Se dirá que la idea confusa, nebulosa, de la muerte le impide la visión porque a veces nos dice que más allá de su horizonte vital hay algo, mientras que otras veces sostiene que no hay nada; algunas 
veces ve penumbras; otras, no anticipa auroras. La verdad es que Balseiro escoge la vursificación que en su criterio más se adapta a la comunicación de la triple carga (intelectual, afectiva y sensorial) que nos va hacer compartir el goce estético. Intelectualmente quiere expresar la duda, de ahí su vacilación en forma y contenido. De las dos preguntas que se hace al comienzo, sólo una logra contestar parcialmente. La muerte es un viaje a lo ciesconocido. Su melancolía ennegrece el fondo de los versos y le empaña la visión; unas veces ve la otra orilla, otras, no.

La segunda parte del libro contrasta con la primera por su claridad y su alegría. Pero las composiciones poéticas, aunque bastante rítmicas, no alcanzan la calidad estética de las anteriores. Valen como parte integrante de la estructura del libro, y sirven para darnos el otro aspecto afectivo, sensorial e imaginativo del autor.

La última parte del libro contiene mejores composiciones y nos da el último estadio de la visión del poeta. La angustia versificada aquí es la angustia de nuestra época, tan elocuentemente expresada en castellano por Unamuno, y en todas las lenguas, por los filósofos existencialistas. En "El erial siniestro" se nos advierte que en cualquier minuto vendrá la última hora de nuestra especie. En "Laberinto" comprobamos que la crisis de todas las conciencias proviene de la ausencia de amor en el corazón de los mortales. A esta falta de amor se debe "el crimen de las manos de cloacas" que perpetraron "los asesinos de la flor de España", en Granada, durante el preludio de la Segunda Guerra Mundial. En "Muerte e inmortalidad de Federico", poema al que pertenecen estos versos, Balseiro le rinde tributo al excelso poeta andaluz y enjuicia a sus verdugos. Como parte de la angustia de nuestro tiempo, la causa del hombre que discrimina al hombre, el antisemitismo queda encerrado en los versos de "Holocausto de Ana Frank", y el dolor del negro en la mejor composición de este ciclo, "La trompeta negra", poema negrista de profundas cualidades estéticas que cala en el alma del negro en el instante de convertir sus sufrimientos en notas musicales.

Podrán hacerle reparos al autor por algo de desorden en la composición y en la estructura del libro, mas no al valor de la mayoría de sus versos. Balseiro nos ofrece en esta colección sus versos más maduros y mejor logrados, demostrán. donos su gran habilidad para el uso de los recursos líricos. Si la segunda parte no se la ha puesto al principio es porque el autor prefiere pasar de la oscuridad a la luz y de ahí a la penumbra enigmática. Para el angustiado contemporáneo esas son las etapas que ha recorrido la humanidad desde la creación. La progresion lírica que interpreta la verdad en el dolor mismo es uno de los caminos que conduce a la redención humana. Las tres fases sucesivas del tránsito de Balseito nos dan la fórmula de su estética, y nos señalan el destino del hombre. Con este libro Balseiro se coloca entre los mejores vates que nos ha dado Puerto Rico.

Eugenio Chang-Rodríguez

Universidad de Pennslyvania, Pbiladelpbics 4, Pa. 
Emilio Carballido, Teatro. México, Fondo de Cultura Económica, Letras Mexi. canas-57, 1960.

Quienes conocen la obra dramática de Emilio Carballido se sorptenderán al leer las muestras contenidas en este volumen, ya que representan una manera nueva en su producción. Con Rosalba y los Llaveros inició Carballido la carrera que, en diez años, le ha llevado a un lugar entre los más destacados miembros de la joven generación mexicana. Comedia deliciosa que no pierde oportunidad de atacar la gazmoñería de la moral provinciana mientras divierte, estableció la trayectoria que después habría de seguir su autor. Igualmente divertida y de pareja agudeza es La danza que sueña la tortuga, mientras que Felicidad es el drama de la clase media baja de México, sin apartarse de la línea realista, comercial -en el mejor sentido- de las dos comedias anteriores. Luego Carballido abandonó esta tendencia en La bebra de oro, exploración de las posibilidades dramáticas del sueño, el subconsciente y el símbolo.

Ahora nos muestra Carballido que está evolucionando hacia un concepto dramático que incorpora el elemento satírico y el valor humano de las tres prinezas obras, y un simbolismo refinado aprendido a través de la experiencia de $L a$ bebra de oro. El presente volumen incluye tres nuevas obras escritas en 1957 y 1958, además de Rosalba y los Llaveros, publicada antes en la desaparecida revista Panorama del teatro en México, de difícil consulta. El relojero de Córdoba de. muestra que su autor no ha perdido las capacidades humorísticas que tanto contribuycron a sus primeros éxitos; es una farsa ubicada en la época colonial, cuyo protagonista es un pobre relojero con alma de poeta, encarcelado a causa de un supuesto crimen. Antes de resolver el problema en favor de un supuesto crimen. Antes de resolver el problema en favor del héroe, Carballido construye una comedia divertida que es, a la vez, una mofa de la llamada justicia oficial. Comedia también es El dia que se soltaron los leones, fantasía simbólica de la necesidad humana de encontrar la libertad que a cada cual le hace falta. Parece paradójico que para uno de los personajes, la libertad estriba en quedarse encerrado en la jaula de leones del Parque Zoológico, y que otro, poeta con ribetes de bohemio vagamundo, la encuentra en el empleo de limpiador de las jaulas. Pero lo que subraya el autor es que la libertad es menos de fuera que de dentro, menos del cuerpo que del espíritu. Se ve que el temario fundamental de las obras anteriores se, conserva en éstas que ahora comentamos; a pesar de la técnica nueva, el teatro de Carballido sigue preocupado por el tema de la libertad del individuo.

La tercera pieza de esta serie es Medusa, leyenda del héroe mitológico que decapitó a la gorgona. Lejos de una tragedia al estilo clásico, estamos frente a una versión moderna, humana, cuyo Perseo es un niño que sueña con la gloria. Si la encuentra es sólo para descubrir que durante la búsqueda se ha endurecido, se ha vuelto hombre con todo su fardo de culpa a cuestas; por algo Carballido emplea como lema unos versos del gran Perseo vencido de Gilberto Owen:

Déjame así, de estatua de mí mismo, la cabeza que no corté, en la mano, la espada $\sin$ honor... 
Entre los aspectos más interesantes de estas obras figura su lucha por desha. cerse del realismo polvoriento. Son altamente estilizadas; a veces se suceden las escenas con una rapidez casi vertiginosa. Los animales de El dia que se soltaron los leones son simbólicos, como se ve en la descripción del gato: "El gato debe ser ficticio, misterioso, nunca un gato vivo". Así son las tres obras; se mueven en un plano irreal, fuera del tiempo concreto; de modo que los valores humanos quedan subrayados, eternizados. No importa que Perseo sea muchacho griego de hace tres mil años; es también muchacho mexicano o de cualquier otra tierra, de hoy o de cualquier tiempo. No es teatro fácil de representar lo que contiene este nuevo volumen de Emilio Carballido. Necesita un escenario enormemente expresivo, sugerente a la vez que sencillo. Ni se podría confiar a actores que no tuvieran flexibilidad suficiente como para acomodarse a una representación estilizada, poética.

El valor de esta nueva colección es doble. Primero, dernuestra plenamente que Carballido es un dramaturgo auténtico y original, capaz de moverse dentro de muy distintos conceptos dramáticos. Segundo, y más importante, nos brinda este volumen tres nuevas obras de positivo valor, que demuestran una vez más la vitalidad del teatro de México.

Universidad de Rutgers,

Frank Dauster

New Brunswick, N. J.

Eduardo Mallea, Posesión, volumen de cuentos, Editorial Sudamericana, Buenos Aires, 1958.

Ésta es la cuarta colección de cuentos del celebrado autor argentino, quien por un aspecto sobresaliente de su obra ha merecido el calificativo de "pintor de almas". En este libro Mallea no defrauda la expectativa del lector que desee ahon. dar una vez más en aquel mundo de angustias y desilusiones que presenta con tanto empeño y, digámoslo, con tanta repetición y uniformidad que ya empieza a cansarnos.

Lo mismo que en sus colecciones anteriores, los tres cuentos de Posesión están ligados temáticamente para conferir cierta cohesión artística al volumen. en La sala de espera (1953), por ejemplo, el eje centralizador es una estación de ferrocarril, donde las siete personas que protagonizan los cuentos esperan la llega. da de un tren; mientras que en La ciudad junto al río inmóvil (1936), el gran Buenos Aires, ostentoso y hueco en su superficie, pero muy digno en su auténtica realidad profunda, parece luchar por revelarse en su aspecto más verdadero y legítimo. La unidad temática de Posesión gira alrededor de un anhelo emocional que resulta todopoderoso $\mathrm{y}$ abrumador en la vida de las tres figuras principales: el anhelo de la posesión. ¿Posesión de qué? He aquí la substancia de los tres relatos. La posesión y dominación de la voluntad de otro es la fuerza determinante del primer telato, que da título a la colección; en el segundo cuento, Los zapatos, es el deseo casi descabellado de poseer un par de zapatos muy costosos; y en Ceilán el deseo de la posesión asuma la forma de una necesidad imperiosa de comunicarse emocionalmente con otra persona. 
En cada caso la creación artística de estos estados de ánimo y disposiciones emocionales es lo que más le interesa a Mallea. Todos los demás elementos del cuento -trama, escena, descripción de personajes- se subordinan a este fin. Noto que la misma excesiva orientación psicológica, tan característica de sus novelas, no sólo persiste en estos cuentos, sino que se manifiesta en un plano casi idéntico. Quizás por la naturaleza misma del cuento y las limitaciones a que está sujeto, esperáramos una técnica distinta de la empleada en sus novelas, una técnica más compacta y directa. Pero la ruta de la ficción malleana ya está predeterminada y tiene que seguirse fijamente, sin desviación de ninguna indole, aun cuando el géne. ro literario exige otra línea artística. Tanto en Posesión como en la gran mayoría de sus novelas, peca Mallea de un exceso de palabras, de una redundancia de ma. teria ideológica tratada en forma de exposición pura, sin verdadera función ficticia. Muchas veces, máxime en los cuentos Posesión y Ceilán, abusa de la paciencia receptiva del lector con interminables disquisiciones de psiquiatría. Casi estoy dispuesto a toletar tal exceso en una novela, con su amplia extensión, gran esfera de acción y desarrollo más bien lento y pausado; en un cuento me resulta menos aceptable, porque choca con los rasgos más propios y distintivos de este género.

En Posesión se entretejen el tiempo actual y el tiempo precedente para indagar la relación extraña entre el protagonista y su antigua amante. La acción actual ocurre en Londres, donde, en una recepción, un tal Videla observa con asombro y resentimiento la atención que un grupo de admiradores le prodiga a cierta mujer elegante y altanera. Videla la conoce; fueron amantes hace años y ahora pasa revista, en forma retrospectiva, a aquella época de su vida. Parece que ella, fuerte, apasionada, orgullosa, se presentó ante él como una presa a quien era preciso conquistar y subyugar. Quería hacerla suya, no sólo en el sentido sexual, sinc como aplastamiento de una fuerza antagónica. Constante lucha entre dos voluntades, que termina en el triunfo de Videla, en la posesión total y absoluta de su amante. Ahora, en la fiesta, muchos años después, ella ya no es la misma mujer vencida, sino una mujer espléndidamente triunfante, muy confiada en sí misma y adorada de cuantos la rodean. Y Videla, herido y agraviado por la paradoja de su aparente posesión, sale cabizbajo de la recepción.

Por el interés del relato, por lo humano del protagonista, y por cierto encanto y viveza de la narración, Los zapatos es tal vez el mejor de los cuentos de este volumen, por cierto el más original. Versa sobre un humilde empleado de oficina a quien le dio el capricho de comprar un par de zapatos carísimo que por casualidad vio en una vidriera. Mallea narra con mucho acierto los grados emocionales por los cuales pasa el protagonista hasta hacer tal compra y los resultados funestos que le acarrea la posesión de estos zapatos. La amistad y cariño que antes tenían por él sus compañeros de trabajo se truecan de repente en frialdad y odio. Resulta víctima inocente de la maledicencia y el recelo de aquellos empleados que no pueden reconciliar esta compra costosa con su carácter modesto y sencillo. Siente con dolor inefable la hostilidad y enojo que encuentra a cada paso, pero su ingenuidad no entiende la razón de este cambio de sentimiento. Cuando le invitan a jubilarse, acepta con resignación su mala suerte, y a poco de encontrarse libre y desocupado parece que se rejuvenece, pues compra una nueva casita y siente los soplos frescos de una nueva vida holgada. Lo que Mallea logra en este cuento es encubrir una cosa bastante pedestre con un hondo significado social; es decir, 
une bien la ligereza de lo exterior del relato con la gravedad de la esencia interior.

El protagonista de Ceilán, llamado Díez, es un personaje de los que tanto abundan en la obra de Mallea: ser solitario, infeliz, errabundo. Si no fuera por el desarrollo lento y pesado de la narración y el excesivo análisis del alma angustiada de Díez, el tema básico del cuento-bien concebido y muy significativo en sítendría mucha más fuerza dramática y refinamiento artístico. A grandes rasgos, Ceilán trata de un tipo egocéntrico e inseguro que siente la necesidad de identificarse emocionalmente con otro ser humano. En una casa de té parisiense que Díez frecuenta mucho, la soledad y desamparo le llevan a trabar amistad con una mujer desconocida que tal vez pueda participar de algún modo en sus pensamientos y emociones. Lo que hace fallta a Díez, más que nada, es la atención humana para escaparse de sí mismo y asentar su vida en la de otro. Pero Díez pronto comprende la imposibilidad de una relación duradera con aquella mujer que sigue guardando en lo más íntimo de su alma el recuerdo vivo de un amante que hace años se suicidó.

¿Qué decir, en resumidas cuentas, de esta colección? Es tan típica de Mallea como La babia de silencio o Todo verdor perecerá. Mallea novelista y Mallea cuentista es uno solo. Si pudiéramos desenmarañar lá red de palabras para descubrir y gozar del sentido y verdad de los relatos, resultaría una experiencia literaria de mucho más valor. Es que nos enfrentamos constantemente con un conflicto básico en la lectura de Mallea: por una parte su prosa es muy original, muy suya, y de gran fuerza y expresión verbal; por otra los excesos y abusos de esta misma prosa restan méritos a su obra como comentario profundo y conmovedor de la vida argentina contemporánea.

\section{MYRON I. LichtBLAU}

Universidad de Syracuse, Syracuse 10, New York.

Alfonso Méndez Plancarte, San Juan de la Ci uz en México, Fondo de Cultura Económica, México, 1959.

Este librito, que tiene el primor literario y tipográfico de una miniatura, expresa principalmente la intima devoción lírica y religiosa de su autor, sacerdote mexicano, hacia la excelsa figura de la mística española que fue Juan de Yepes, el carmelita descalzo elevado a los altares con el nombre de San Juan de la Cruz. El primer capitulo, "Vida Incandescente", es una bella estampa biográfica del humilde frailecillo que tanto padeció, como Fray Luis de León, por efecto de las rivalidades frailescas. En el segundo, se recogen valiosas opiniones críticas sobre la producción poética de San Juan de la Cruz, que aparte de sus méritos intrínsecos tiene el de haber sido creada espontáneamente y sin definidos propósitos literarios.

El título del libro queda justificado en los capítulos siguientes, dedicados a poner de relieve la reverberación literaria que San Juan de la Cruz ha tenido en los escritores mexicanos de los siglos xvI al xx. Sólo un manuscrito anónimo puede 
citar del primero, pero en cambio hace referencia al propósito que Fray Juan de la Cruz tuvo de trasladarse a México, viaje a América que también desearon probablemente no sólo Cervantes sino otros grandes escritores, como Fray Luis de León, Góngora y Fray Luis de Granada. Respecto del siglo xvir, el autor cree encontrar positivas huellas de la influencia del místico español en poemas del Obispo de Puebla don Juan de Palafox y Mendoza.

No podía el mexicano Méndez Plancarte resignarse a que no existieran huellas del gran carmelita español en la obra de Sor Juana Inés de la Cruz, que no encontró, por cierto, Menéndez Pelayo. Tras iluminada búsqueda, el autor de este libro pudo decifrar un leve indicio por el cual Sor Juana "nos viene a hacer palpable su conocimiento y recuerdo de San Juan de la Cruz, al menos con vehemente probabilidad".

Por lo que se refiere a los siglos XviI, xIx y $\mathrm{xx}$ muestra el autor que efectivamente hubo influencias de San Juan de la Cruz en poetas mexicanos, si bien por lo que concietne a la presente centuria no ticne alta categoría de poeta, entre los escritores que Méndez Plancarte cita, más que Alfonso Reyes, cuya reciente pérdida ha privado a la literatura hispanoamericana de uno de los hombres más ilustres.

La investigación de las recíprocas influencias entre las literaturas hispánicas es sin duda labor de interés sumo. Se habla de la influencia del barroquismo sobre Sor Juana, de Rubén Darío sobre los modernistas españoles, de Ortega y Gasset sobre la actual generación literaria hispanoamericana. Pero quedan muchas por estudiar, y sin duda el trabajo de Méndez Plancarte es valioso, reflejo además de un interés muy estimable. Hay en él solamente, según mi parecer, una opinión que considero absolutamente errónea. Conocía el autor muy poco a Salvador Dalí y por ello concede a algunos de sus cuadros un valor místico del que verdaderamente carecen, perque en el tan famoso pintor catalán el misticismo no pasa de ser una pirueta.

Universidad de lowa,

JERónimo Mallo

lowa City, Lowa.

Boyd G. Carter, En torno a Gutiérrez Nájera, Ediciones Botas, México, 1960.

Éste es el segundo volumen que el distinguido investigador norteamericano doctor Boyd G. Carter ha dedicado a problemas najerianos, siendo el primero $\mathrm{Ma}$ nuel Gutiérrez Nájera: Estudio y escritos inéditos, Colección Studium, México, 1956. En el presente libro, el autor vuelve a estudiar, más detalladamente y con muchos datos nuevos, varios problemas tratados en el Estudio. Importante entre éstos es el que se refiere a la paternidad de algunos escritos firmados por " $M$. Gutiérrez", que se publicaron en El Correo Germánico y otros periódicos mexicanos en 1875 y 1876. El autor nos indica que Gutiérrez Nájera, a pesar de su tierna edad (16 años) fue un colaborador importante del Correo durante sus dos 
meses y medio de existencia: desde el $1^{\circ}$ de agosto hasta el 14 de octubre de 1876. Durante este período se publicaron en el periódico cinco piezas (cuatro artículos en prosa y un poema) firmadas por "Manuel Gutiérrez Nájera", y cinco poesías firmadas por "M. Gutiérrez". El doctor Carter se preguntó, en el Estudio, si "M Gutiérrez" padría ser uno de los muchos seudónimos que usó "El Duque Job", y sostuvo en los periódicos un debate muy interesante con el crítico mexicano Porfirio Martínez Peñaloza, quien afirmaba que "M. Gutiérrez" fue Manuel Gutiérrez y Gómez, padre del poeta, de quien conocemos varios escritos en prosa y en verso, y hasta en forma dramática, con la firma de "Manuel Gutiérrez", "M. Gutiérrez" o "M. G."

Dos de las poesías publicadas en el Correo ya habían aparecido sin firma y bajo una forma que se diferenciaba bastante de la del Correo, en La Ilustración Mexicana en 1851, es decir, antes del nacimiento de MGN. Sugiere el Dr. Carter en el presente volumen, y apoya su opinión po: medio de un análisis detallado de las piezas de que trata, que Manuel conocía las poesías publicadas en La llas. tración Mexicana, que en efecto eran de su padre, y con el consentimiento de éste las refundió, con muchas adiciones, supresiones y cambios de fraseología. Nota el crítico que el material nuevo que se halla en la versión de 1876 de las dos poesías tiene muchas características en común con las poesías originales que publicara el futuro "Duque Job" hacia la misma época. Por eso cree que en estos casos "M. Gutiérrez" es otro seudónimo suyo, aunque normalmente lo empleaba su padre. El mismo tipo de análisis convence al Dr. Carter de que otras tres poesías en El Correo Germánico y aun una que se publicó en otro periódico, son de Gutiérrez Nájera, aunque llevan la firma de "M. Gutiérrez". El Sr. Martínez Peñaloza está de acuerdo con Carter en que dicha conclusión es plausible, pero hasta que no tengamos pruebas objetivas prefiere considerarla como teoría más bien que como un hecho.

Pero el libro de Carter trata de otras muchas cosas de gran importancia. Dedica un capítulo a la vida y los escritos de Gutiérrez padre, y recoge por primera vez varias de sus poesías. Cita artículos de varios periódicos de la época que tratan de las actividades públicas y culturales de Gutiérrez padre y comenta: "En estos artículos se nos of rece un concepto interesantísimo del ambiente cultural en que pasó Manuel sus años formativos". Nota que durante la juventud de Manuel su padre era redactor de El Propagador Industrial, donde el hijo publicó algunos de sus primeros escritos. Fue también por medio de su padre como Manuel conoció al Barón de Brakel-Welda, redactor de El Correo Germánico.

Otro capítulo trata de las relaciones literarias de Gutiérrez Nájera con Emile Zola. Se demuestra que tres por lo menos de los cuentos de MGN publicados en Cuentos completos (Fondo de Cultura Económica, México, 1958), son adaptaciones o imitaciones de otros de Zola: "La inundación" está relacionado con uno de "Les quatre journées de Jean Gourdon". "El sueño de Magda" con "L'Inondation" y "Las fresas" con "Les fraises", uno de los Nouveaux contes à Ninon.

En el largo capítulo tiutlado "La mexicanidad de Gutiérrez Nájera" el autor trata el problema bajo tres encabezamientos: "Gutiérrez Nájera y Francia", "Manuel y Alemania", y "Gutiérrez Nájera y México". Dice que las relaciones de MGN con Francia fueron sumamente importantes, y para indicar la índole de éstas inserta, entre otras, la cita siguiente de Luis G. Urbina (La vida literaria de 
México, México, 1946): "Es que desde la invasión de los soldados de Napoleón III, México experimentó, en las clases media y alta, la irresistible influencia de ese pueblo tan comunicativo y sugestivo. Al retornarse las tropas extranjeras después de cuatro años... quedaron en el país muchos franceses... y entre ellos hubo quienes se dedicaran a la instrucción y abrieron colegios. Esto determinó, entre otras causas, la propagación del idioma y la literatura de la nación invasora. Gutiérrez Nájera, por efecto de sus recientes estudios... se afrancesó... de día en día el contagio es evidente; el galicismo empieza a aparecer; salta la alusión exótica; entra sin anunciarse el modismo extranjero; habla la cita intrusa en idioma extraño y tiene la retórica atrevidas novedades. El libro y el ambiente iban modelando a Gutiérrez Nájera; iban formando sus ideas y su estilo..."

No está de acuerdo el Dr. Carter con el juicio de Justo Sierra: "pensamien tos franceses en versos españoles, he aquí su divisa literaria". Según él, "el afrancesamiento del Duque Job no consistirá sino en la asimilación... de maneras de ver, sentir, reaccionar y escribir de muchos escritores y periodistas france. ses. Esto quiere decir que ... no pidió prestado un contenido, compuesto de 'pensamientos franceses', sino que antes bien adquirió, por medio de sus observaciones y de acreciones involuntarias, formas de expresión apropiadas a su particular visión artística y a su genio personal".

Según el parecer del Dr. Carter, la influencia de Alenania en el desarrollo artístico de Manuel fue mucho menos importante que la de Francia. Se muestra sobre todo en dos series de artículos publicados en 1876: "Páginas sueltas, por Agapito Silva", en La Iberia, 10,11, 12, 13 y 14 de mayo, y "El arte y el materialismo", en El Correo Germánico, 5, 8, 17, 24, 26 de agosto y 5 de septiembre. En los artículos del 12 y 13 de mayo, sobre todo, se encuentra un elogio fervoroso de la cultura alemana, y especialmente del lied como género literario. Entre los escritores que han cultivado con más éxito esta forma, enumera a Heine, Uhland, Geibel y Rückert, en Alemania, y a Bécquer en España. Como anota el Dr. Carter, aunque sabemos - por estos artículos sobre todo-que en su juventud Manuel adniró mucho la cultura aleniana y sobre todo el lied, "... debemos admitir que hasta ahora no hemos podido identificar (la nota gernánica en las poesias de GN)".

También anota el autor que aunque Martínez Peñaloza ve en "El arte y el materialismo" paralelos entre el pensamiento de Manuel y el de Hegel sobre la naturaleza y los fines del arte, podemos reconocer en otros escritores de más o menos la misma época, sobre todo en Hugo (Prefacio de Cromwell) y en Gautier (Prefacio de Mlle. Maupin) ideas muy semejantes a las de Hegel. Concluye el Dr. Carter: "A pesar del entusiasmo de Manuel por Alemania por el año de $1876 \ldots$ otras influencias se apoderaron de su imaginación y al parecer, no volvió a interesarse por aquel país y su cultura sino de manera casual".

Con respecto a "Gutiérrez Nájera y México", el autor encuentra extraño que la crítica se haya ocupado tan poco de la mexicanidad de GN. Anota como ejemplo de su interés por lo mexicano sus descripciones de la ciudad de México, con gran acopio de nombres de calles, plazas y parques, y hasta de edificios y casas de comercio. Abundan en sus escritos cuadros de costumbres mexicanas: "Las páginas de Gutiérrez Nájera encierran comentarios sobre el día de muertos, el 16 de septiembre, la Noche Buena, el quemar de Judas, la fiesta de la virgen, proce- 
sión de Corpus; noche de San Silvestre, el Año Nuevo, la mañana de San Juan, la apertura del Congreso, hombres políticos, héroes, patriotas, tiendas, teatros, restaurantes, clubs, actores y actrices, escritores, platos mexicanos, hoteles, carruajes, tranvías, fuegos de artificio, trasnochadores, cortesanas, jugadores, los hermanos Gayosso, y cien otros aspectos de la vida mexicana de aquel tiempo".

Anota el autor que GN tenía la costumbre de leer en las colecciones de periódicos los escritos inéditos de autores mexicanos, y que la influencia de algunos de ellos se puede notar en su propia formación literaria e ideológica. Menciona especialmente, en este particular, a Antonio F. Grilo y Francisco Zarco.

La mexicanidad de GN se ve también, dice nuestro autor, en ciertos rasgos de su personalidad: “. . . en su hondo sentido de lo trágico y lo irónico de la vida, en su concepto de la soledad como inevitable corolario de toda existencia humana, en su sentido religioso... en lo simpático de su personalidad, en su genio festivo y en su cortesía, gentileza y comportamiento aristocrático..." Cita en este sentido el juicio del crítico mexicano Ermilo Abreu Gómez ("Manuel Gutiérrez Nájera", en Letras de México, $1^{\circ}$ de marzo de 1945): "Acaso fue MGN el más entrañablemente nacionalista de su tiempo. Ni en Darío... ni en Gómez Carrillo... se encuentra tanto sabor, tanto regusto por la cosa propia... Bastará leer fragmentos de su prosa y su poesía... para advertir que, a través de sus novísimas formas, estaba presente, con presencia viril, el aliento de su vida mexicana, dulce, católica y hasta, en ocasiones, irónica".

Termina el volumen con un apéndice que presenta varios poemas de Manuel Gutiérrez padre y otros de escritores mexicanos que se relacionan con los escritos juveniles de MGN, y una bibliografía de obras y documentos consultados por el autor en el curso de sus investigaciones.

En este volumen el Dr. Carter ha añadido muchas cosas de gran valor a sus investigaciones sobre Gutiérrez Nájera, y por eso merece la gratitud de todo admirador del vate mexicano.

Universidad de Iowa,

ERWIN K. MAPES

Iowa City, Iowa.

Manuel Pedro González, Antología crítica de José Martí. Recopilación, introducción y notas de... [Universidad de Oriente, Departamento de Extensión y Relaciones Culturales, Santiago de Cuba]. México, D. F., Publicaciones de la Editorial Cvltvra, T. G., S. A., 1960.

Desde 1935 Manuel Pedro González se viene ocupando de la abra de José Martí. Por lo menos es de aquella fecha su primer trabajo martiano, "La revaloración de Martí", que fue escrito para la revista Nosotros, de Buenos Aires, y que, debido a la suspensión temporaria de ese benemérito órgano cultural, apareció dos años más tarde (1937) en Fichero, de La Habana. "Acotaciones en torno a su bibliografia", dice, modestamente, el subtítulo de la reproducción en volumen (Estudios sobre literaturas bispanoamericanas. Glosas y semblanzas, México, Ediciones 
Cuadernos Americanos, 1951, pp. 133-150). Es en verdad una revisión a fondo de la bibliografía martiana de 1895 a 1935 y en ella se apuntan algunos temas que el propio autor retomará más adelante: los de las relaciones de José Martí con los Estados Unidos y con Rubén Darío, por ejemplo.

Sin embargo, este trabajo no era más que un adelanto de la obra mayor que Manuel Pedro González preparó "a lo largo de más de veinte años de laboriosas pesquisas": las imprescindibles Fuentes para el estudio de José Martí. Ensayo de bibliografia slasificada (La Habana, Publicaciones del Ministerio de Educación, DDirección de Cultura, 1950, volumen I de la serie de "Bibliografía Cubana", como no podía ser de otra manera. En el prólogo, titulado "Significación de José Martí", Manuel Pedro González estampó lo siguiente: "Como otros muchos, hubo una época en que soñé escribir un libro sobre Martí -tema que a tantos ha tentado- pero decidí que era más necesario y más útil a la gloria del Maestro, reunir y clasificar por lo menos parte de lo mucho que sobre él se ha escrito para facilitat su estudio a los que en el futuro quieran ahondar en su análisis". Tres años después de dicha declaració, Manuel Pedro González publicó su José Martí, Epic Cbronicler of the United States in the Eighties (With an Introduction by Sturgis E. Leavitt, Chapel Hill, The University of North Carolina Press, 1953), obra sobre cuyo tema se han escrito varias monografías, pero que por haber aparecido en inglés y dirigida en especial al público norteamericano ha contribuido notablemente en la difusión del nombre de Martí en los Estados Unidos. Hay que advertir que a la aparición de este libro la bibliografía de Martí en inglés sólo contaba con la traducción de Martí, el apóstol, de Jorge Mañach (Marti, Apostle of Freedom, traducción de Coley Taylor, New York, The DevinAdair Co., 1950); una antología de textos de Martí referentes a los Estados Unidos (The America of José Martí, traducción de José de Onís, con prólogo de Federico de Onís, New York, The Noonday Press, 1953) se publicó un poco después en el mismo año. Lo mismo cabe decir de la obra de Félix Lizaso, Martí, mistico del deber (Marti, Maytyr of Cuban Independence, traducción de Esther Elise Shuler, Albuquerque, University of New Mexico Press, 1953).

De entonces a la fecha Manuel Pedro González ha escrito una serie de ensayos sobre diversos aspectos de la obra de José Martí, que reunidos formarían un volumen más denso que el anteriot. En el Primer Congreso de Escritores Martianos, celebrado en La Habana en febrero de 1953 para conmemorar el primer centenario del nacimiento de Martí, presentó dos ponencias: I) "Iniciación de Rubén Darío en el culto a Martí", y II) "Resonancias de la prosa martiana en la de Dario", que fueron incluidas después en la Memoria correspondiente (La Habana, Publicación de la Comisión Nacional Organizadora de los Actos y Ediciones del Centenario de José Martí, 1953) y ocupan en ella 67 páginas. Al año siguiente apareció su "José Martí, anticlerical irreductible" en Cuddernos Americanos, enero-febrero de 1954, año xiii, vol. 1xxiii, No. 1, pp. 170-197). A la Miscelánea de estudios dedicados al Dr. Fernando Ortiz por sus discípulos, colegas $y$ amigos (La Habana, 1956) contribuyó con un ensayo sobre "José Martí: jerarca del modernismo", y al Libro jubilar de Emeterio S. Santovenia en su cincuentenario de escritor (La Habana, 1957), con otro sobre la "Conciencia y voluntad de estilo en Marti". Finalmente, en un breve volumen de Notas en torno al modemismo (México, Universidad Nacional Autónoma de México, 1958), "se in- 
cluyen dos artículos: "De una amistosa polémica con Juan Marinello en la que se ventilaba el carácter y alcance del modernismo tanto como la consanguinidad de la estética martiana con la de los más destacados representantes de aquel movimiento" y una extensa reseña sobre la Sección constante, de José Martí, que exhumó Pedro Grases de La Opinión Nacional (Caracas, 1955; pero también en las "Acotaciones a El poema en prosa en España" (obra antológica de Guillermo Díaz-Plaja publicada en 1956), incluidas en las Notas en torno al modernismo, destaca Manuel Pedro González, con preciosa documentación y con fino criterio, características relevantes del estilo de Martí, lo mismo que su preeminencia y prioridad en la renovación de la prosa artística en lengua española.

Así pertrechado nuestro autor, nos presenta hoy esta Antología crítica de José Martá, cuyos únicos defectos - adelantémoslos de una vez-son o se nos antojan: una cierta ambigüedad semántica en el título y la exclusión no jusitficada de un ensayo cuando menos del propio antólogo. Porque este macizo volumen es realmente una magnífica "Antología de estudios sobre Martí,, tal como la llama, con sencillez y precisión, Manuel Pedro González en la nota de "Explicación y gratitud" que la precede, y no una 'Antología de la obra de crítica de José Martí u otra 'Antología muy exigente de José Marti', como podría momentáneamente pensarse. Y siendo, como en efecto' lo es, una 'Antología de la crítica sobre José Martî', muy rigurosa por cierto, no debió excluirse de ella, por prurito de innecesaria modestia, su propio estudio sobre la "Conciencia y voluntad de estilo en Marti", aunque figurara al lado de los excelentes ensayos de Alfredo A. Roggiano ("Poética y estilo de José Marti") y de José Antonio Portuondo ("La voluntad de estilo en José Martí"), pues sólo la literalidad de su título, no el contenido, importa una repetición. También pudo Manuel Pedro González sustituir "La huella de Martí en Rubén Dario", de Osvaldo Bazil, trabajo bien superado ya por el antólogo con sus propias ponencias sobre la "Iniciación de Rubén Dario en el culto a Marti" y sobre las "Resonancias de la prosa martiana en la de Dario", verdaderas aportaciones originales.

La Antología está dividida en tres secciones: "Estudios sobre la prosa de José Marti" (quince piezas), "Estudios sobre José Martí, poeta" (ocho) y "Estudios sobre las ideas de José Marti" (siete). La primera contiene Ios ensayos ya clásicos de Darío, Gabriela Mistral y Unamuno y los de Juan Ramón Jiménez, Federico de Onís y Max Henríquez Ureña, bien conocidos y valorados. Hay que subrayar las aportaciones de los ensayistas más recientes como Roggiano, Portuondo y Anderson Imbert, de las que no se podrá prescindir en el futuro, seguramente. Otros ensayos son firmados por martianos distinguidos, como Medardo Vitier, Fina García Marruz y Juan Marinello. Antes nos referimos al de Osvaldo Bazil y ahora al del crítico español Guillermo Diaz-Plaja, buen conocedor de Martí.

Los "Estudios sobre José Martí, poeta" debieron encabezarse por el del mismo título de Rubén Dario, de acuerdo con la cronología de las piezas, como se hizo en la sección anterior. El de Gabriela Mistral sobre los Versos sencillos, como el de "La lengua de Marti" merece sobradamente la inclusión; son ensayos que dicen tanto de Martí como de ella misma. De la crítica moderna sobre la poesía de Martí (Eugenio Florit, Juan Carlos Ghiano, Roberto Ibáñez y Cintio Vitier) la más abarcadora es la de Ghiano, la más sensible Ia de Florit; todas iluminativas de alguna obra o de un aspecto poético de Martí. Los ensayos de José María 
Chacón y Calvo y de José J. Arrom se complementan mutuamente :son necesarios para el cabal conocimiento de "José Martí, poeta".

Las piezas sobre las ideas de Martí están suscritas casi exclusivamente por cubanos, si se exceptúan las "Reflexiones" de D. Fernando de los Ríos y el ensayo de Andrés Iduarte, trabajos estimados desde su primera publicación. Los ensayos de Mañach y Piñera son de lo más setio que se ha escrito sobre el tema. Los dos de Miguel Jorrín son los más ceñidos y enjundiosos. El de Medardo Vitier completa muy eficazmente las venerables "Reflexiones" de D. Fernando de los Ríos. El volumen se cierra con una bibliografía mínima de y sobre Martí, destinada a los lectores extranjeros no familiarizados con la obra y la crítica martiana.

La calidad de la selección de estos estudios y la utilidad de tenerlos a mano en un solo volumen es innegable. Los estudiosos de Martí y de las letras hispanoamericanas estarán siempre agradecidos con el modesto pero riguroso compilador. Ya es tiempo que los grandes autores hispanoamericanos dispengan de obras como ésta y no sólo de elogios y panegíricos. Estudio, comprensión y valorización es lo que necesitan.

Biblioteca Nacional,

ERnesto Mejía Sánchez

Universidad de México.

Eduardo Neale-Silva, Horizonte bumano. Vida de José Eustasio Rivera. México, Fondo de Cultura cEonómica, 1960, 506 pp. + ind. (Colección "Tierta Firme", No. 66).

Es ésta una biografía surgida de una necesidad interna del crítico, la de "conocer la vida del poeta para comprender mejor su obra"; Neale-Silva la ha plasmado con sorprendente objetividad, absteniéndose en lo posible de formular juicios estéticos sobre la producción literaria de Rivera, pero sin ignorar las relaciones existentes entre la vida y la obra. Poseedor de una riquísima documentación periodística y oral, ha podido trazar el desarrollo de la compleja personalidad de Rivera y describir el ambiente físico y espiritual en que se formó, como labor previa a la exégesis literaria; el mismo Neale-Silva nos lo dice: "pensamos insistir sobre sus méritos artísticos en trabajo aparte".

Pero aun cuando esta exégesis quedara por desgracia en mero proyecto, tenemos sobrado motivo para estar satisfechos de esta Vida de José Eustasio Rivera. Es modelo de solvencia documental y de fino análisis sicológico. Lenguaje sencillo y claro, sin repujos de estilista, que cumple cabalmente la secuencia narratiav y el rigor de la exposición. Si Neale-Silva no cumple lo prometido, no podríamos reprochárselo excesivamente, porque en realidad ya ha hecho mucho con presentar el "horizonte humano" de Rivera. Con hilos fuertes a la vez que delicados ha tejido esa "insonsútil tela" que es una vida; sólo falta ahora saber leer 
"el revés de la trama". Esto puede hacerlo Neale-Silva u otra persona de sus capacidades y que tenga como él amor por la obra de Rivera.

Con detenimiento y documentación apropiada el biógrafo rectifica las fechas y circunstancias del nacimiento y la muerte de Rivera, y narra ssu polémicas y afanes literarios, sus viajes al Perú, México y los Estados Unidos, sus estudios y preparación cultural, sus experiencias de aventurero y explorador y sus proyectos editoriales, todo ello con espíritu objetivo y sin ningún alarde de "biografismo". Pero Neale-Silva no ha querido detenerse en las exterioridades de la vida del hombre y de su ambiente. Ha penetrado resueltamente en la sique del creador y en los modos peculiars dl país y del continente que lo produjo, describe los encontrados movimientos del corazón del poeta y las manifestaciones públicas de Colombia frente al hombre y la obra. Y el biógrafo ha hecho más aún: nos adentra en la gestación y escritura de Tierra de promisión y La vorágine. De aquí en adelante tendrán que partir Ios trabajos críticos de Neale-Silva.

En la "Introducción" encontramos observaciones y planteamientos que ya el crítico ha resuelto por anticipado en el ejercicio biográfico: "El estudio de la vida de un literato nos lleva a establecer la relación entre el hombre y su creación artistica... Una fuente de falsas suposiciones es la obra misma de Rivera: Tierra de promisión (1921) y La vorágine (1924). Muchos hay que han tomado por autobiográficos no pocos detalles que en realidad son ficticios". Pero no está de más señalar que estos problemas han sido planteados en el plano teórico, pero con abundantes ejemplos de la literatura iuniversal, por Alfonso Reyes en sus Tres puntos de exegética literaria (1945), especialmente en el segundo sobre "La vida y la obra", y en los ensayos sobre "La biografía oculta" y "Detrás de los libros", de La experiencia literaria (1942), obras que Neale-Silva no puede desconocer.

Biblioteca Nacional,

ERnesto Mejía SÁnchez Universidad de México.

\section{Emilo Carilla, El Romanticismo en la América Hispánica (Madrid: Editorial Gredos [Biblioteca Romántica Hispánica, Estudios y Ensayos, 40], 1958).}

El índice de materias de este libro (págs. 507-512) es un espléndido programa de estudio del romanticismo americano. Ofrece, tras la presentación del ambiente histórico y del concepto de lo romántico, el examen de las influencias europeas y el de las doctrinas y polémicas americanas del romanticismo; a continuación, el de la lengua, la métrica, los géneros y los temas, con un detalle de las generaciones románticas y de la transición del romanticismo al modernismo; y acaba con una panorámica visión del romanticismo brasileño.

El contenido del libro muestra claramente los méritos y las dificultades del intento de una obra de tal envergadura en nuestro momento.

Entre los méritos se cuenta el caudal de lecturas del autor en las literaturas de los países hispánicos desde el Bravo a Magallanes. La extensión geográfica y 
temporal del empeño hace que el referido mérito se halle contrabalanceado por la dificultad a veces de obtener textos importantes. Es evidente al examinar las notas de pie de página que el Sr. Carilla ha tenido que recurrir con harta frecuencia a antologías y colecciones para hallar algunos. No es esto siempre cierto, claro está: Los materiales primarios de las literaturas del Río de la Plata, Chile, Venezuela y Colombia, por ejemplo, parecen haberle sido más accesibles que los de los demás países americanos de lengua española. Parecidas dificultades debieron surgir en el empleo de trabajos críticos.

La dificultad principal reside en que es muy difícil escribir una obra totalizadora sobre el romanticismo en la América hispánica cuando aun carecemos en demasiados casos de estudios monográficos a fondo sober el romanticismo en distintos paises y sobre escritores no sólo menores sino incluso mayores de dicho movimiento. No es pues superficialidad lo que afecta al contenido de la obra sino la lucha constante entre la ambición de hacer labor sintetizadora y la resistencia de un material insuficientemente trabajado; insuficientemente trabajado, entiéndase bien, no por el Sr. Carilla sino por el cuerpo de investigadores de la literatura hispánica. Quizá la lección más valiosa que se saque de este libro es que hay mucho qué hacer en el estudio de este aspecto de la literatura ochocentista americana. El Sr. Carilla ha organizado lo que hay, mérito no pequeño, pero no ha podido realizar sólo lo que ha de ser labor preliminar de muchos.

Este libro marcará así una etapa en el estudio del romanticismo en América y de él puede deducirse un programa de estudios indispensables para que dentro de veinte años pueda otro trabajador tan laborioso como el Sr. Carilla dar un paso adelante en la nueva sintetización de los materiales que se descubran por inspiración de nuestro meritísimo contemporáneo.

Conviene decir, pues, que tanto por su utilidad como por su insuficiencia este libro merece bien de las letras de lengua castellana.

Universidad de Californit,

LuIs MONGUIó

Berkeley, California.

Guillermo de TORRE, Claves de la literatura hispanoamericana. Cuadernos Taurus, 27, Madrid, 1959.

En este ensayo, diestramente realizado y ya anticipado parcialmente en un número reciente de la Revista Hispanica Maderna (XXV, Nủ.m 3, julio de 1959, pp. 185-198), el crítico Guillermo de Torre nos ofrece unas posibles claves de interpretación para sintetizar lo más característico de la literatura hispanoamericana. Sin dogmatismos ni rigideces, propone trazar un indice teórico de sus constan. tes y sus coordenadas más esenciales. De hecho, el libro nos parece no sólo un diagnóstico sino también, a la vez, un pronóstico. Desde luego, la grat diversidad y pluralidad de las letras hispanoameticanas se resisten a la deseada síntesis y dificultan la tarea del crítico, pero, en su visión de conjunto, Guillermo de Torre 
ha podido soslayar en todo lo posible parcialidades $\mathrm{y}$, por lo demás, quiere evitar herir las hipersensibilidades nacionalistas.

Quisiéramos señalar en este libro cierta flexibilidad discursiva, propia, es verdad, del género que maneja con tanta maestría el ensayista, y también cómo el crítico se apoya más en sus experiencias directas y contactos diarios con la misma vida literaria de Hispanoamérica que en teorías establecidas a priori. Pero no por esto deja de acoger autorizadas opiniones de otros críticos (Pedro Henríquez Ureña, Alfonso Reyes, Picón Salas, Borges, etc.). Además toma la preocupación de no avanzar afirmaciones categóricas e irresponsables; prefiere discutir, plantear e interrogar en vez de dogmatizar. Este tono dubitativo tiende a quitar toda clase de agresividad polémica a sus páginas y asegura con qué habilidad Guillermo de Torre sabe eludir muchos riesgos inherentes a tan ambicioso enfoque. Por otra parte, conviene anotar una cosa que indudablemente favorece las inducciones del crítico: nos referimos a su bien conocida familiaridad con las literaturas europeas, de las que es uno de los más asiduos comentadores, y también a su posición actual de equidistancia entre las dos literaturas hispánicas. Nada de espíritu localista, pues. $Y$ escribe desde una perspectiva rtgurosamente intelectual, o si se quiere universal, y no nativista. De ahí, quizá, surja algún reparo a su modo de ver esas literaturas. Finalmente importa advertir que el intento de Guillermo de Torre en la crítica literaria acompaña, guardando las debidas proporciones, a los escritores americanos de distintas latitudes, tanto creadores como ensayistas, que actualmente se dedican, con seriedad y ahinco, a una indagación sobre su razón de ser espiritual e intelectual.

Este es un libro pequeño en su tamaño pero nada limitado en su alcance. Así puede justificarse la desmesurada extensión de la pesente nota, que aspira sencillamente a exponer con toda objetividad ciertas opiniones y conclusiones a que llega Guillermo de Torre en $\tan$ interesante ensayo. Abre un sin fin de sugerentes perspectivas, algunas de ellas aptas para el más variado comentario. Por la naturaleza del tema estudiado, es evidente que el libro pueda despertar reacciones de las más diferentes según y cómo uno vea la literatura hispanoamericana. ¿Cuáles son, pues, estas claves de interpretación y cuál es el método que utiliza el ensayista en la presentación de sus materiales?

Para Guillermo de Torre la literatura hispanoamericana es, desde sus primeros momentos, una continuación o derivación de la española. No nace, pues, de manera súbita con la Independencia sino con el Descubrimiento. Hispanoamérica tiene también sus clásicos de la época colonial, escritores surgidos simultáneamente con otros españoles, pero con un carácter propio e individual sin que este tono nuevo los separe de la literatura matriz. Si bien el sustrato español determina la unidad espiritual y lingüística de las repúblicas hispanoamericanas, tal identidad originaria no excluye nuevos matices y tonalidades genuinamente americanos. Sin embargo, el crítico descubre una primera clave permanente en la resistencia de Hispanoamérica a esa tradición, en la tensión que existe con respecto a las derivaciones españolas. Tal conflicto se explica, desde luego, por el deseo de buscar y de encontrar una personalidad propia.

En seguida nos hace observar que la evolución histórica de la literatura his: panoamericana produce la impresión de cierto asincronismo y discontinuidad. Juzgada esa literatura con criterio europeo, es verdad que hay muchos anacronismos, 
pero tal característica no es definidora ni exclusiva por las muchas expresiones sincronistas que no escapan a la mirada historicista. Hasta España tiene-el caso más notorio es el modernismo- sus propios anacronismos con respecto a América. No obstante, según puntualiza Guillermo de Torre, no deja de reaparecer una misma suerte de discontinuidad en el siglo actual. Ejemplo capital citado y, por lo demás, obra de primera categoría: Don Segundo Sombra, en que se recrea sentimentalmente una vida casi primitiva con todas las técnicas más avanzadas que Güiraldes aprendió en la estética francesa. Así, pues, el crítico halla como rasgo característico de gran parte de la literatura hispanoamericana la conjugación de lo que él denomina elementalismo y refinamiento. Otras novelas de la misma época pudieran citarse también para sostener la tesis de esta misma fusión del tema criollo cón los procedimientos artísticos más bien europeos de novelar. Precisamente la superposición y coexistencia de estilos, no sólo en la literatura sino también en las artes plásticas, viene a ser una cualidad distintiva de la expresión artística en Hispanoamérica. Vale la pena transcribir las palabras textuales de Guillermo de Torre: "Este mestizaje de elementos constitutivos... se nos aparece como el común denominador, como la constante más definitoria de las letras hispanoamericanas. Es - reiterémoslo- primitivismo y refinamiento conjugados; aparte de los casos apuntados, se personifica en los hombres de acción del siglo xIX que son al mismo tiempo literatos; se expresa en la alternancia de propagandismo político y esteticismo quintaesenciado; traduce, en último término, la amalgama de dos espíritus y tendencias: europeísmo y americanismo". (p. 33).

En las páginas finales, de vuelta ya en unas premisas fundamentales de su Hispanoamérica obras dignas de cualquier literatura, obras de categoría internacional? Estas interrogantes y otras muchas llevan a Guillermo de Torre a toda una serie de reflexiones, con frecuencia problemáticas, que no carecen de interés, y las diferencias regionales o nacionales frente a los rasgos más bien generales, cuyas lineas generales merecen ser brevemente resumidas. Insistir demasiado en supone una limitación porque se cierra por lo menos un camino para la plena comprensión de esa literatura, no sólo en el extranjero sino también en las naciones vecinas. Otra consecuencia del mismo particularismo es la conocida incomunicación entre las repúblicas hermanas. Se llama atención sobre la admirable curio sidad extravertida de Hispanoamérica, pero desgraciadamente ésta suele ser unilateral, orientándose casi siempre hacia Europa. Para Guillermo de Torre la solución ha de encontrarse en una integracion que funda lo propio y lo adquirido. Así puede ser combatida toda tendencia escisionista. No es cuestión, pues, de volverse de espaldas a lo europeo para acoger por encima de todo lo indígena, sino de formar una más amplia conciencia continental que permita así ensanchar fronteras dónde fijar el punto en que comienza el uno y termina el otro. Para fines de tal deslinde rechaza por falaces e insuficientes los temas y las particularidades idiomáticas y ve como lo propiamente americano "un acento más emocional que rigutituye una clave diferenciadora de la literatura peninsular.

Aceptada la existencia de la literatura hispanoamericana en su totalidad, lo la vitalidad de ciertas formas literarias, desde la Edad Media en adelante, cons. No se le olvida a Guillermo de Torre relacionar este fenómeno con la literatura tesis, Guillermo de Torre recalca la importancia de lo español en 'a formación y española en que abundan los "frutos tardíos" (Menéndez Pidal). Y seguramente 
más espinoso del tema es establecer la unidad de una literatura dentro de toda y derribar barteras. Revisadas brevemente algunas teorías de lo americanc (inclusive la de H. A. Murena), el crítico pregunta cómo diferenciarlo de lo europeo y raturas? ¿Cómo establecer jerarquías válidas dentro de la frondosidad? ¿Tiene la consabida fragmentación y heterogeneidad propia de Hispanoamérica. Parece que prevalezcan las diferencias sobre las coincidencias. ¿Cómo abarcar en una mirada de conjunto la plurivalencia de rasgos difnidores de una veintena de literosamente intelectual". (p. 65).

desartollo del espíritu hispanoamericano: "la cultura de raíz hispánica es, ha sido y seguirá siendo una presencia irremplazable, necesaria, en el mundo hispanoamericano." Pero, ante de que se escandalicen los americanistas más violentos, citemos las siguientes palabras del crítico: "Presencia, sí, pero no preeminencia que implique un trato de favor" (p. 69). Los remedios propuestos por el ensayista no son, pues, unilaterales sino que marcan un término medio que quiere rehuir todo exclusivamente extremista. Se da por satisfecho si se puede correr en América la cortina de desconfianza ante los valores peninsulares. Recomienda una vez más la necesidad de un "diálogo de literaturas", tema abordado por el thismo en varios trabajos anteriores, un diálogo franco y sin sentimentalismos de ninguna clase. Para realizar tan alto ideal de reciprocidad intelectual (y la palabra clave es reciprocidad), será necesario extirpar en España la incuriosidad y la indiferencia por cosas americanas. Asimismo en América cierta actitud, si no de rechazo, por lo menos de independencia con respecto a la Peninsula. Sólo así se puede llegar a una máxima comprensión que supere la dispersión y la diversidad, formulando además una tabla de valores que permita deslindar un balance auténtico de lo muerto y lo vivo de las letras hispanoamericanas. Es decir, Guillermo de Torre se interesa en las posibilidades sustantivas y afirmativas de un internacionalismo literario.

Finalmente llega a preguntarse: "¿Será excesivo pronosticar que cuando este continente pierda o sobrepase la obsesión de su 'autonomía cultural', ésta será la señal de que verdaderamente ha llegado a poseerla?" (p. 80) No es pesimista ni severo en su modo de encararse con la literatura hispanoamericana. Ve en las generaciones jóvenes una cada vez mayor exigencia, lo cual llva a una nueva etapa de madurez en toda Hispanoamérica. Cree en la posibilidad de una expresión auténticamente universal con tal de que se mantenga una posición de interdepen. dencia cultural; se eliminen las complacencias y exageraciones nacionalistas; y se cultiven motivos y sentimientos que trascienden lo meramente localista.

Universidad de Chicago,

Allen W. Phillips Chicago, Illinois.

Manuel Gutrérrez Nájera. Obras; crítica literaria, 1 . Centro de Estudios Literarios, Universidad Nacional Autónoma de México. México, 1959.

En 1953, diez años después de publicar las Obras inéditas: Poesias y crónicas de "Puck" (Nueva York, 1943), E. K. Mapes, infatigable investigador y perito 
en la obra de Nájera, observó atinadamente que "una de las rarezas de nuestro estudio del Modernismo consiste en que siempre hemos juzgado a Manuel Gutiérrez Nájera por una parte muy pequeña de su obra ("Manuel Gutiérrez Nájera, seudónimo y bibliografía periodística," RHM, XIX, 132). A partir de 1956 los devotos del "Duque Job" iniciaron la magna labor de recoger sus numerosos escritos que vieron la luz, firmados con diversos seudónimos, en periódicos y revistas mexicanos del siglo pasado. Con la publicación del libro de Boyd G. Carter, Manuel Gutiérrez Nájera; Estudio y escritos inéditos (México, 1956), se dio el primer paso. Luego, en 1958, los Cuentos completos y otras narraciones, coleccionados y ordenados cronológicamente por el Profesor Mapes, contribuyeron al mayor conocimiento del desarrollo del estilo narrativo najeriano. El libro que aquí se reseña, organizado también en forma cronológica y dividido en dos partes - "Ideas y temas literarios"; "Literatura mexicana"- es el primer tomo de una edición que promete reunir la obra dispersa del poeta mexicano.

La ausencia, hasta muy recientemente, de una edición cronológica de los escritos de Nájera ha imposibilitado los estudios estilísticos de su prosa, y, en particular, la comparación de su prosa artística con la de modernistas coetáneos. Hace años, en cambio, que la poesía está ordenada cronológicamente, y hoy, puede decirse, la tenemos completa -o casi en su totalidad-en la excelente edición de Francisco González Guerrero, Poesias completas (México, 1953).

Este volumen de prosa, lo mismo que el que E. K. Mapes publicó en 1958, debe ser considerado a la luz de los estudios recientes - de Max Henríquez Ureña, Federico de Onís y Manuel Pedro González-, de los que ha resultado una revaloración del movimiento modernista. La crítica actual, confrontada con las conclusiones de los arriba mencionados investigadores, ha rectificado la cronología del Modernismo, la que fijaba su comienzo en 1888 , y, a la vez, guiada por la Estilística, ha concedido el merecido valor a la prosa artística, cuna del estilo modernista. Los iniciadores de esta prosa fueron dos artistas que trabaron amistad en México entre 1875 y 1877: Manuel Gutiérrez Nájera y José Martí. Por consi. guiente, la nueva edición de la prosa de Nájera, patrocinada por el Centro de Estudios Literarios de la Universidad de México, proporcionará valiosísimos datos a quienes se interesan en la primigenia prosa modernista, y en las afinidades, coincidencias y diferencias en el estilo de ambos iniciadores del Modernismo. En las ochenta y ocho piezas de teoría y crítica literaria que integran este tomo, hay una rica veta de recursos formales de que se sirvieron los modernistas en la elaboración de su estilo, algunos de los cuales Nájera usaba conscientemente en 1876: impresionismo, simbolismo, sinestesia, parnasismo, simbolismo cromático, y una técnica relacionada con el impresionismo, denominada "la trasposición pictótica" por Ernesto Mejía Sánchez.

En la primera parte del libro (págs. 47-106), bajo el rótulo de "Ideas y temas literarios", están recogidos los ensayos en que Gutiérrez Nájera expone sus ideas teóricas sobre la literatura. Estas piezas, once en total, revelan la soltura y autoridad con que, desde muy temprano en su carrera literaria -1876- el bardo mexicano manejaba temas estéticos. Uno de los aspectos más relevantes de estos artículos -amén de su riqueza ideológica-es la similitud de algunos de los conceptos expresados ya expuestos por Marti, y aunque la preceptiva najeriana nunca 
alcanzó el máximo desarrollo ni la fecundidad de la martiana, a los dos artistas cupo el honor de inaugurar el estilo modernista y de formular una teoría literaria correspondiente entre 1875 y 1885.

La segunda sección de las Obras (págs. 109-539) reproduce aquella parte de la crítica literaria de Nájera que versa sobre las letras mexicanas; las setenta y siete piezas incluidas bajo el título de "Literatura mexicana" of recen un verdadero panorama caleidescópico de la actividad cultural de México en los últimos decenios del siglo diecinueve. A pesar de la premura con que, en su mayoría, estos artículos fueron escritos, en ellos Nájera demuestra su dominio del arte de la crítica. Con frecuencia es generoso, a veces severo; en ocasiones se sirve del humor y la sátira; pero en todos sus juicios valorativos se transparenta el artista consumado cuyas extensas lecturas en las literaturas de Grecia, Roma, España, Francia, Alemania, Hispanoamérica y los Estados Unides, le facilitaron las ideas indispensables para enjuiciar la obra de sus compatriotas con plena justicia.

Este volumen de las cibras del "Duque Job" quizá no hubiera visto la luz hoy sin las investigaciones del Profesor Mapes, quien identificó y fotografió en micropelícula casi todos los ensayos. A Ernesto Mejía Sánchez debemos la copiosa información bibliográfica, la pulcritud general de la edición, y, sobre todo, las abundantes $\mathrm{y}$ eruditas anotaciones que arrojan luz sobre nombres, títulos y acontecimientos mencionados en las piezas.

Las Obras van precedidas por una magnífica introducción de Porfirio Martínez Peñaloza (págs. 15-43); en ellas el prologuista analiza las fuentes de las ideas teóricas de Nájera, discute las lecturas que, con toda seguridad, moldearon sus nociones estéticas, y, por fin, estudia la crítica literaria de la época en que Nájera ejerció el periodismo. Nos alegra que el Señor Martínez Peñaloza le conceda a "Puck" su justo lugar dentro del Modernismo, llamándole "iniciador" (pág. 29), y no "precursor". Mas no nos explicamos por qué pone en tela de juicio la autenticidad de la metáfora huguesca "L'art c'est l'azur" (pág. 27), que Eduardo de la Barra reprodujo en el prólogo a la primera edición de $A z u l$. ., citando con fidelidad de una sección intitulada "Le Beau, serviteur du Vrai" de Willian Sbakespeare, obra en que Hugo utiliza la frase varias veces. Sin embargo, esta inexactitud no desdora en absoluto un libro tan cuidadosamente preparado y que constituye una contribución de primera categoría a la bibliografía najeriana.

Washington University,

IVAN A. SCHULMAN

Saint Louis, Missouri

Marco Antonio Montes de Oca, Delante de la luz cantan los pájaros, Editorial Fondo de Cultura Económica [Colec. Letras Mexicanas, Núm. 50], México, 1959.

Este nuevo título del poeta mexicano Marco Antonio Montes de Oca es su cuarto libro publicado y, al mismo tiempo, constituye su obra completa. Si se 
observa el orden de las respectivas publicaciones que precedieron a dicho título, podrá deducirse que la denominación correspondiente al lugar de Delante de la luz cantan los pájaros sería "Ofrendas y epitafios", subtítulo éste de una de las cuatro partes en que está dividido el libro, por cierto la que hasta ahora no había sido recogida en volumen ya que cada una de las otras tres partes se subtitulan de la misma manera que cada uno de los tres poemarios publicados anteriormente.

Montes de Oca, nacido en 1932, se dio a conocer con Ruina de la infame Babilonia (1953), poemario que le proporcionó elogios y augurios felices, animándole, incluso, a publicar un segundo que denominó Contrapunto de la fe (1955); el éxito se repitió y nuevamente el autor buscó a los editores para entregarles su tercer poemario: Pligo de testimonios, volumen infortunado que los críticos no recibieron con igual entusiasmo.

El poeta desde su comienzo mostró seguridad en el paso, por ello, desde entonces, no hubo ningún contrasentido al afirmarse que sus creaciones lo descubrían como a un artista maduro no obstante su juventud; ninguno podía negar calidad a quien con un tomo primigenio ya era autor de versos como éstos que se encuentran en Ruina de la infame Babilonid:

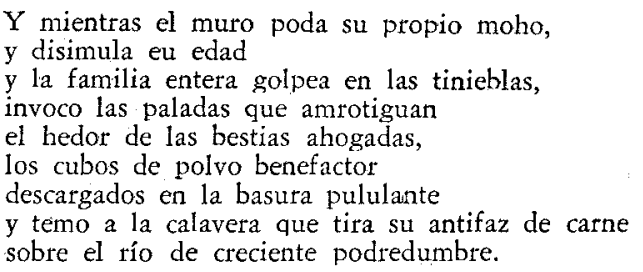

Esta forma de construir el poema es casi solitaria en la historia de la poesía mexicana; el grupo de poetas más respetado en México, el reconocido como "generación de Contemporáneos", al que integra nombres prestigiados como el de Carlos Pellicer y José Gorostiza, no fincó ninguna clase de antecedentes literarios de esta índole. Buscando conexiones podría retrocederse al año 1922, cuando Manuel Maples Arce con su libro Andamios interiores encabezó la inquietud "estridentista" ansiosa de nuevos cauces para la expresión literaria, pero aquí, cualquier semejanza, sólo hace referencia al atrevimiento de la imagen, pues Maples Arce es - como corresponde a su momento-menos serio que Montes de Oca, de modo que se debe avanzar sobre el año 1924 para leer de Maples algunas construcciones poemáticas aparecidas en Urbe:

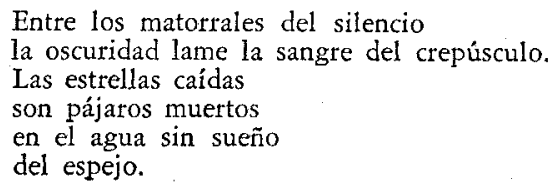

Este es ya, podríamos decir, el Maples serio, meditativo sobre la nueva figura literaria que desea revolucionar el ambiente poético, sin embargo, su seriedad no 
Io acerca a la elaboración de Montes de Oca, quien sin pretender revolucionar construye el poema aprovechando la experiencia depuradora sufrida durante 30 años por los ismos de vanguardia; pot otra parte, la poesía del poeta joven refleja, en el manejo de la palabra, modelos ejemplares tales como. Xavier Villaurrutia y Octavio Paz.

Ahora bien, toda la obra de Marco Antonio Montes de Oca a excepción de Pliego de testimonios está concebida dentro de un juego de imágenes puramente creacionistas, huidobrianas, como gusta Antonio de Undurraga - iese gran poeta chileno!- que se conciba el poema. El libro excepcionado, el tercero, es un libro que da la idea de haber sido scrito con urgencia, buscando para expresar el concepto una mayor síntesis en la imagen; para el poeta debe ser un libro doloroso porque porque descompensa su calidad creativa debido a su cerrazón, a su oscuridad; sufre con él un estancamiento. Sin ser un libro estéril no abona nada sobre lo que aportaron los dos primeros. Apenas hay intentos, esfuerzos, $\sin$ llegar a verdaderas realizaciones.

Al reunir en Delante de la luz cantan los pájaros toda su poesía, Marco An. tonio Montes de Oca ha procurado no olvidar las experiencias propias, recordar los pronunciamientos de la crítica contra Pliego de testimonios, así como también las sugestiones de amigos que ahondaron por igual sobre los tres libros y la necesidad de recurrir al mayor pulimento, ganar en claridad, economizar lenguaje $y$, quizá, - sin menoscabo de la delimitación formal--acercarse a humanizar aquellos períodos poéticos que dan la impresión de estar mineralizados, de ser simple enumeración de imágenes, colección bellísima de joyas que al ser tocadas molestan por su frialdad, por su abandono de la mano del hombre. Montes de Oca no desaprovechó la lección y consciente de la responsabilidad que implica en nuestro tiempo ganar el reconocimiento de poeta, modificó de distintas maneras tanto los poemas que ya habían sido recogidos en libros como los que conforman el grueso de su producción más reciente.

A fin de dar una idea -como corresponde a las limitaciones de espacio propias de este trabajo- de lo que para el poeta mexicano significó la experiencia antes apuntada, es necesario referirse a Contratunto de la fe y Pliego de testimonios, adelantando que ambos libros al ser reeditados fueron rigurosamente aumentados, corregidos y disminuidos, lo que explica una segunda versión de cada uno de ellos.

Contrapunto de la fe en su primera versión inicia el poema con este verso: "La tierra apelmazada en las uñas"; y en la más reciente: "Ei hombre es tan libre como un halcón"; o sea que el autor coloca al bombre en un primer plano como se constata en versos posteriores. Enseguida, aparecen muchas partes del poema donde se eliminan versos o se cambian palabras que en la primera versión habían empañado la transparencia estética; sirvan estos ejemplos:

$1^{a}$ versión

Muerto el halcón, no delante de mi pregunta deshollada, $2^{a}$ versión

Muerto el halcón nace la vida con su rocío de ojos de caballo, 
si en la nuca del centinela naces, vida, con tus rocíos de ojos de con sus tristes y enormes pequeñeces con tus enormes pequeñeces, [caballo, que no esperábamos los mortales.

con tu asesino domingo siete que no esperábamos los mortales.

$\mathrm{Y}$ un ejemplo de búsqueda de la claridad para exponer el concepto puede apreciarse aquí:

$$
1^{a} \text { versión }
$$

¿Tiemblas marino, es mucha la joya del para tus párpados... $2^{\sharp}$ versión

¿Tiemblas marino, resplandece demasia[do la joya del sol y no soportas el tormento de sus párpa-

Pliego de testimonios en su primera versión está integrado por cuatro poemas; a cambio, en la segunda han sido agregados estos dos: "En el umbral de la plegaria" y "La vieja alianza". El poema titulado "El jardín que los dioses frecuentaron" en su segunda versión ha perdido 19 versos y ha ganado una cita de Hölderlin, aparte que desde el principio pueden anotarse mutaciones benéficas como éstas:

\section{$1^{a}$ version}

Extranjera es la luna en la noche sólo poblada con dos aman-

[tes.

Niniguna cuña de maravilla cabe en [esa esfera que no lanza de sí ni su aliento, pues todo sirve a su robusta plenitud, $2^{a}$ versión

Extranjera es la luna en la noche sólo poblada con dos aman-

[tes.

Ella y él, en impaciente simulacro, siegan con el tajo de la vista las espigas púrpuras de los fuegos de

En Pliego de testimonios son numerosas las modificaciones no sólo de versos o de conjunto de versos sino inclusive de simples palabras; la transcripción de algunos casos es útil para ilustrar lo referente a estas últimas modificaciones en las que se substituye un vocablo por otro más adecuado o que es de mayor exactitud; veamos dos o tres de dichos casos:

$$
1^{\text {a }} \text { versión }
$$

el ocio de intensas figuras

con que la luna amuebla el agua

$\ldots \ldots \ldots$

Deslizándose, arqueándose como un ti[gre de aire delicioso

El amor piensa de nuevo en su perdida

$$
\begin{array}{r}
\text { a..... perdida } \\
\text { [esfera }
\end{array}
$$

\section{$2^{*}$ versión}

el ocio de intensas figuras con que la luna invade el agua

Deslizándose, arqueándose como una [pantera de aire delicioso El amor rebace de nuevo su perdida [esfera

Delante de la luz cantan los pájaros aporta una enseñanza poética a la par de una enseñanza de humildad; ésta, es la que nos da un poeta joven al reela- 
borar y dar un sentido a tres libros que habían cumplido ya una misión artística. Es más, sin sactificar el tono arquitectónico de los poemas, el estilo, las inflexiones del poeta, se entra con amor al terreno de las figuras literarias que pugnan por una mayor lógica expresiva. Marco Antonio crea y re-crea, torna a Vicente Huidobro sin olvidar su propio aliento, sin traicionarse; sabe que "escuchando y cantando / el hombre renueva su palabra"; así lo canta él y así renueva su voz.

Mauricio de la Selva

Universidad de México. 